\title{
Pathophysiological Roles of Endothelin Receptors in Cardiovascular Diseases
}

\author{
Mamoru Ohkita ${ }^{1}$, Masashi Tawa ${ }^{1,2}$, Kento Kitada $^{1,3}$, and Yasuo Matsumura ${ }^{1, *}$ \\ ${ }^{1}$ Laboratory of Pathological and Molecular Pharmacology, Osaka University of Pharmaceutical Sciences, \\ 4-20-1 Nasahara, Takatsuki, Osaka 569-1094, Japan \\ ${ }^{2}$ Department of Pharmacology, Shiga University of Medical Science, Otsu, Shiga 520-2192, Japan \\ ${ }^{3}$ Department of Pharmacology, Kagawa University Medical School, \\ 1750-1 Ikenobe, Miki-cho, Kita-gun, Kagawa 761-0793, Japan
}

Received January 11, 2012; Accepted June 4, 2012

\begin{abstract}
Endothelin (ET)-1 derived from endothelial cells has a much more important role in cardiovascular system regulation than the ET-2 and ET-3 isoforms. Numerous lines of evidence indicate that ET-1 possesses a number of biological activities leading to cardiovascular diseases (CVD) including hypertension and atherosclerosis. Physiological and pathophysiological responses to ET-1 in various tissues are mediated by interactions with $\mathrm{ET}_{\mathrm{A}^{-}}$and $\mathrm{ET}_{\mathrm{B}}$-receptor subtypes. Both subtypes on vascular smooth muscle cells mediate vasoconstriction, whereas the $\mathrm{ET}_{\mathrm{B}}$-receptor subtype on endothelial cells contributes to vasodilatation and ET-1 clearance. Although selective $\mathrm{ET}_{\mathrm{A}^{-}}$or nonselective $\mathrm{ET}_{\mathrm{A}} / \mathrm{ET}_{\mathrm{B}}$-receptor antagonisms have been assumed as potential strategies for the treatment of several CVD based on clinical and animal experiments, it remains unclear which antagonisms are suitable for individuals with CVD because upregulation of the nitric oxide system via the $\mathrm{ET}_{\mathrm{B}}$ receptor is responsible for vasoprotective effects such as vasodilatation and anti-cell proliferation. In this review, we have summarized the current understanding regarding the role of ET receptors, especially the $\mathrm{ET}_{\mathrm{B}}$ receptor, in CVD.
\end{abstract}

Keywords: endothelin-1, endothelin receptor, endothelial cell, vascular smooth muscle cell, cardiovascular disease

\section{Introduction}

Endothelin (ET) derived from vascular endothelial cells (ECs), which consists of a 21 amino acid peptide, has a strong and persistent vasoconstrictive action (1). ET has three family peptides (ET-1, ET-2, and ET-3). As the distribution and properties of these peptides are different, each peptide is believed to play specific physiological roles. ET has two types of receptor: the $\mathrm{ET}_{\mathrm{A}}$ receptor with a high affinity for ET-1 and ET-2 is mainly located on muscle cells, whereas the $\mathrm{ET}_{\mathrm{B}}$ receptor with an affinity for all three peptides lies on endothelial, epithelial, endocrine, and nerve cells. Of the three ET iso-

*Corresponding author. ymatsumura@gly.oups.ac.jp Published online in J-STAGE on July 21, 2012 (in advance) doi: 10.1254/jphs.12R01CR

Invited article forms, ET-1 plays a much more important role in the regulation of vascular tone than the others and has a powerful effect on the cardiovascular system. Thus, the role of ET-1 and its receptors as the etiology or precipitating factors in various cardiovascular diseases (CVD) has been investigated $(2,3)$. In addition, numerous studies have reported effective treatment targeted at ET-1 in pulmonary hypertension, salt-sensitive hypertension, diabetes, and acute and chronic kidney diseases using ETconverting enzyme (ECE) inhibitors and ET-receptor antagonists $(2,4)$. Several animal models genetically lacking ET-1 and ET receptors have also been used as a tool for determining the physiological and pathophysiological roles of ET-1 and ET receptors in CVD $(5-10)$.

\section{ET system}

ECs are known as the main physiological source of vascular ET-1. Vascular smooth muscle cells (VSMCs), 
macrophages, leukocytes, cardiomyocytes, and fibroblasts are also capable of ET-1 production $(11-13)$. Several studies have indicated that various physical and chemical factors such as thrombin, angiotensin II, cytokines, hypoxia, and shear stress stimulate ET-1 gene expression in ECs by DNA binding of transcription factors including activator protein-1, GATA-2, Smad, nuclear factor-kappa B (NF- $\kappa \mathrm{B})$, and hypoxia inducible factor-1 $(14-18)$. On the other hand, ET-1 is synthesized as an inactive 203-amino-acid precursor, preproET-1, which is proteolytically cleaved to yield a second inactive 39 (or 38)-amino-acid segment called 'big' ET-1. The last part of the proteolytic process is mainly carried out by ECE (ECE-1 and ECE-2) and leads to the production of the bioactive form of 21-amino-acid peptide ET-1. As ET-1 release from ECs is constitutive, ET-1 biosynthesis and release appear to be mainly controlled via regulation of gene transcription and/or ECE activity.

The downstream effects of ET-1 are mediated by two G-protein-coupled receptors $\mathrm{ET}_{\mathrm{A}}$ and $\mathrm{ET}_{\mathrm{B}}$. In the vasculature, the $\mathrm{ET}_{\mathrm{A}}$ receptor on VSMCs mediates vasoconstriction and cell proliferation, whereas the endothelial $\mathrm{ET}_{\mathrm{B}}$ receptor (generally called $\mathrm{ET}_{\mathrm{B} 1}$ ) exerts opposite effects. Stimulation of the $\mathrm{ET}_{\mathrm{B} 1}$ receptor leads to the release of vasodilators such as nitric oxide (NO) and prostaglandin $\mathrm{I}_{2}$ and clearance of ET-1 from the circulation within the lungs, kidneys, and liver $(19-23)$. On the other hand, although another $\mathrm{ET}_{\mathrm{B}}$-receptor subtype $\left(\mathrm{ET}_{\mathrm{B} 2}\right)$ located on VSMCs exerts vasoconstriction, it has become clear that $\mathrm{ET}_{\mathrm{B} 2}$ receptor-induced vasoconstriction is negligible under normal conditions but becomes more important in some kinds of diseases such as atherosclerosis and essential hypertension $(24-26)$.

Many vascular relaxing or contraction factors produced in the blood vessel wall maintain normal endothelial function by mutually antagonistic actions. In particular, there are various reports regarding the interaction of ET-1 and NO (27). For instance, ET-1 binding to the $\mathrm{ET}_{\mathrm{B} 1}$ receptor leads to phosphoinositide 3-kinase (PI3K) activation and subsequent production of phosphatidylinositol-3,4,5-trisphosphate, which results in recruitment and activation of protein kinase B / Akt (28). This $\mathrm{PI} 3 \mathrm{~K} / \mathrm{Akt}$ pathway is responsible for the phosphorylation and activation of endothelial NO synthase (eNOS). On the other hand, ET-1 also reduces eNOS expression and its activity through increases in hydrogen peroxide by the $\mathrm{ET}_{\mathrm{A}}$ receptor (29). Therefore, reduced $\mathrm{ET}_{\mathrm{B}}$-receptor function and/or overactivation of the $\mathrm{ET}_{\mathrm{A}}$ receptor eliminate the protective function by $\mathrm{NO}$ in vessels and promote the pathological formation of various circulatory diseases (Fig. 1).

\section{Pathophysiological roles of ET receptors}

\subsection{Cardiac disease}

Myocardial infarction results from the formation of an atherosclerotic plaque and ultimately leads to heart failure. Several studies have reported elevations in plasma ET-1 levels in patients with coronary artery diseases such as angina (30), myocardial infarction (31), and immediately after percutaneous transluminal coronary angioplasty (32). In addition, the production and release of ET-1 as well as ET-receptor expression is enhanced during myocardial ischemia/reperfusion $(33,34)$. Thus, these findings suggest that endogenous ET-1 plays an important role in the pathophysiology of myocardial ischemia/reperfusion.

Locally generated ET-1 contributes to tissue repair or remodeling of the infarcted heart in an autocrine/paracrine manner, thereby exerting an immediate beneficial effect on damaged tissue $(33,34)$. Other studies reported that ET-1 administered prior to the onset of ischemia exhibited cardioprotective effects $(35,36)$. Exogenous ET-1 mimics the cardioprotective effect of pre-conditioning against infarction, apparently via $\mathrm{ET}_{\mathrm{A}}$ receptormediated activation of PKC and a mitochondrial type of ATP-sensitive $\mathrm{K}^{+}$channel $(37,38)$. On the other hand, a substantial and long lasting rise in ET-1 induces myocardial hypertrophy, which is associated with a maladaptive effect on myocardial structure and function, thereby leading to fatal events $(39-42)$. The $\mathrm{ET}-1 / \mathrm{ET}_{\mathrm{A}}$ receptor pathway also promotes myocardial fibrosis by enhancing cardiac fibroblast proliferation, adhesion molecule expression, and extracellular matrix deposition $(43,44)$. Therefore, the use of ET-receptor antagonists, mostly targeting the $\mathrm{ET}_{\mathrm{A}}$ receptor, provides beneficial effects in chronic heart failure as evidenced by a reduced infarct size, improved reperfusion coronary flow, or protection during ischemia/reperfusion $(39-42)$.

In myocardial ischemia, sympathetic overactivity accompanied by excessive norepinephrine (NE) release is associated with cardiac dysfunction and arrhythmia, thereby exaggerating primary ischemia and initiating a malignant cycle that can cause further myocardial damage and high-risk cardiac dysfunction $(45,46)$. Both $\mathrm{ET}_{\mathrm{A}}$ and $\mathrm{ET}_{\mathrm{B}}$ receptors exist in the sympathetic nerve varicosities of guinea pig hearts and exhibit opposite effects on NE release in association with reperfusion arrhythmias: $\mathrm{ET}_{\mathrm{A}}$ receptors evoke $\mathrm{NE}$ release, whereas $\mathrm{ET}_{\mathrm{B}}$ receptors prevent it (47). Previous studies showed that a selective $\mathrm{ET}_{\mathrm{A}}$-receptor antagonist or the combination of $\mathrm{ET}_{\mathrm{A}}$ - and $\mathrm{ET}_{\mathrm{B}}$-receptor antagonists suppressed excessive NE release from sympathetic nerve endings in postischemic rat hearts and improved cardiac dysfunction after ischemia/reperfusion $(9,47)$. In addition, exogenous 


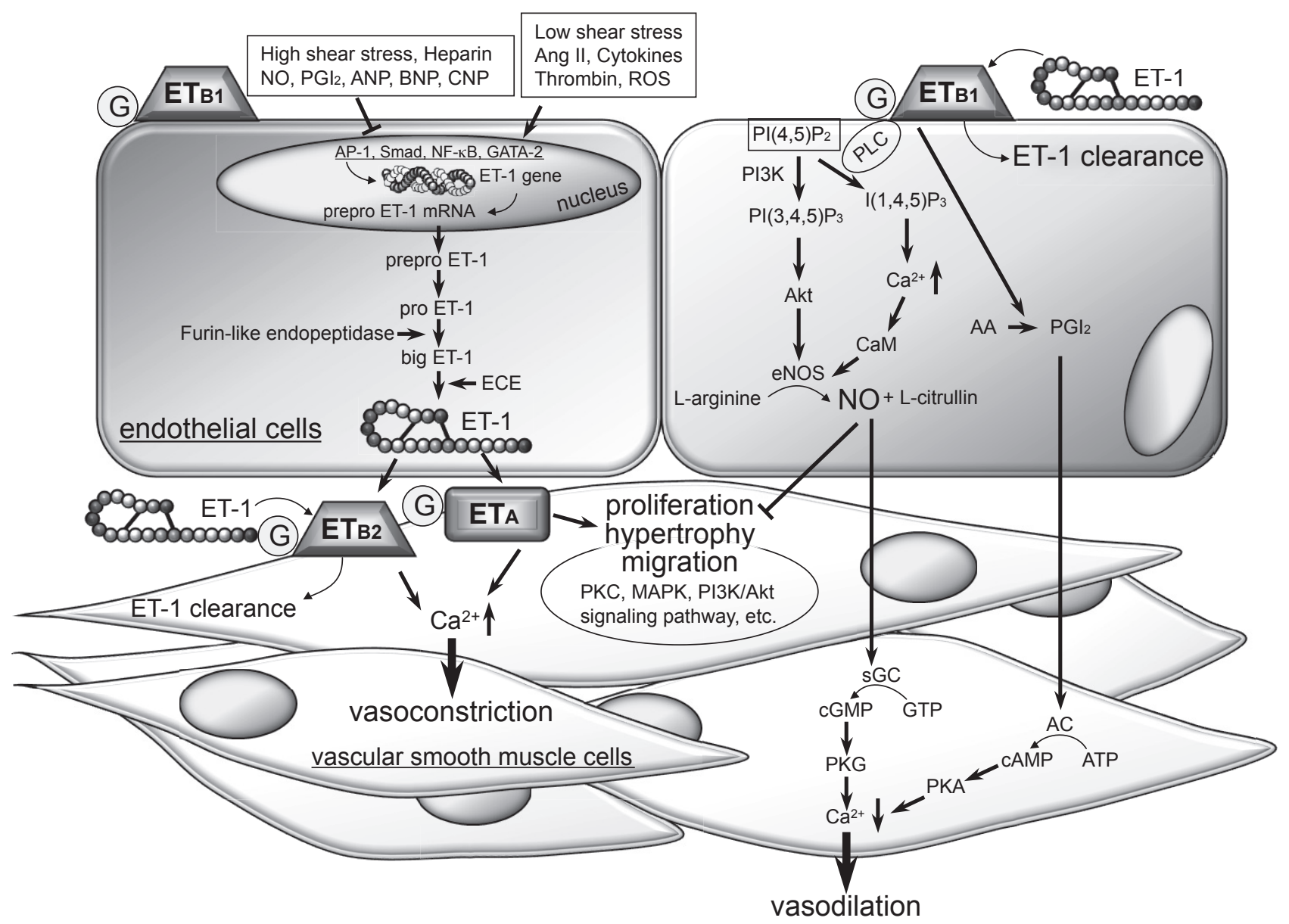

Fig. 1. Schematic illustration of ET-1 production and ET receptor-mediated actions on vascular endothelial cells and smooth muscle cells. G: G protein, ROS: reactive oxygen species, CaM: calmodulin, AA: arachidonic acid, $\mathrm{PGI}_{2}$ : prostaglandin $\mathrm{I}_{2}, \mathrm{AC}$ adenylate cyclase, sGC: soluble guanylate cyclase.

ET-1 induced excessive NE release and subsequent cardiac dysfunction, counteracted with the $\mathrm{Na}^{+} / \mathrm{H}^{+}$exchanger (NHE) inhibitor 5-( $N$-ethyl- $N$-isopropyl)-amiloride (EIPA). Thus, the excessive NE overflow triggered by the ET-1 / $\mathrm{ET}_{\mathrm{A}} / \mathrm{NHE}$ pathway seems to be contributive to post-ischemic cardiac dysfunction in rats (Fig. 2). On the other hand, both pharmacological blockade and genetic deficiency of $\mathrm{ET}_{\mathrm{B}}$ receptors exaggerated the postischemic excessive NE release and cardiac dysfunction. Oikonomidis et al. demonstrated that NE levels during the early phase of myocardial infarction are much higher in $\mathrm{ET}_{\mathrm{B}}$-deficient rats than wild-type rats and this contributes to the incidence of ventricular arrhythmogenesis, thereby suggesting that the $\mathrm{ET}_{\mathrm{B}}$ receptor exerts a suppressive effect in sympathetic hyperactivity during the early phase of myocardial infarction (48). Furthermore, activation of the $\mathrm{ET}_{\mathrm{B}}$ receptor with sarafotoxin-6c substantially reduced NE release, myocardial infarct size, and ischemic arrhythmias $(47,49)$. Taken together, acti- vation of the $\mathrm{ET}_{\mathrm{B}}$ receptor may likely prevent postischemic cardiac dysfunction through the attenuation of NE release.

Big ET-1 exerts several physiological actions similar to ET-1, but it must be converted to ET-1 via enzymatic degradation by ECE (50). ECE expression and its enzyme activities are increased in myocardial infarction (51), thereby suggesting that a selective ECE inhibitor may be useful in ischemic cardiac diseases at the clinical level, which warrants further attention. In fact, SM-19712 and FR901533, both of which are highly selective ECE inhibitors, exert a desirable influence on myocardial infarction by decreasing plasma concentrations of ET-1 (52, 53). On the other hand, exogenously applied big ET-1 has qualitatively similar effects to ET-1 in the cardiovascular system in vivo and in vitro $(54-57)$. Against this background, Sharif et al. demonstrated that exogenously applied ET-1 exhibited opposite effects to endogenously released ET-1 on ischemic ventricular arrhythmias (58). 


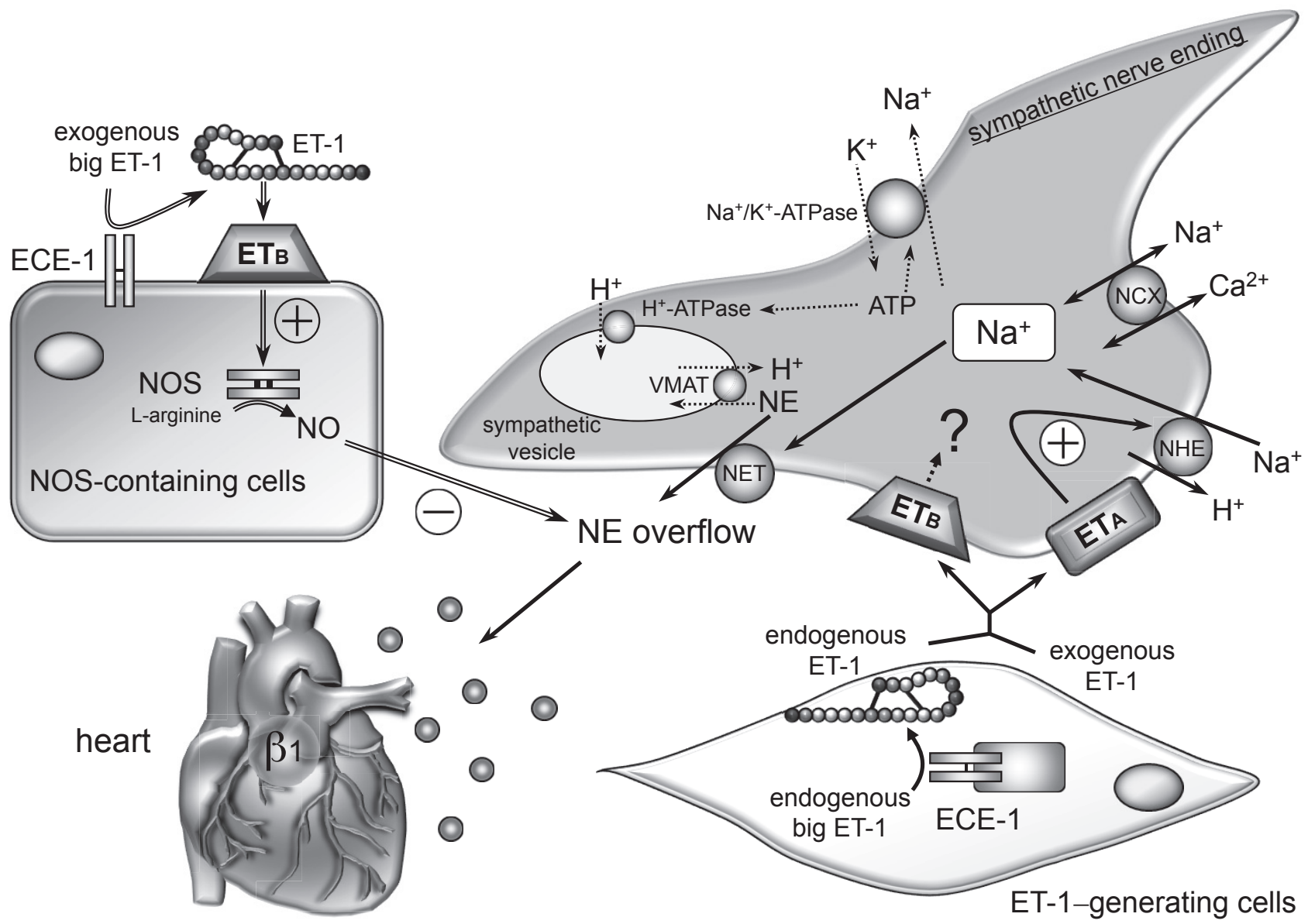

Fig. 2. Proposed explanation for the interaction between the ET-1 system and norepinephrine (NE) release from cardiac sympathetic nerve endings in protracted myocardial ischemia. ATP is depleted and axoplasmic $\mathrm{pH}$ is reduced under ischemic conditions. This diminishes vesicular storage of NE, leading to a large increase in free axoplasmic NE. Compensatory activation of the neuronal $\mathrm{Na}^{+} / \mathrm{H}^{+}$exchanger (NHE) by axoplasmic acidification causes influx of $\mathrm{Na}^{+}$in exchange for $\mathrm{H}^{+}$. The resulting $\mathrm{Na}^{+}$accumulation triggers a massive release of free axoplasmic NE via a reversal of the NE transporter (NET). Released NE acts on postsynaptic adrenoceptors on myocytes. Stimulation of the $\mathrm{ET}_{\mathrm{A}}$ receptor existing in sympathetic nerve endings by endogenously generated or exogenously applied ET-1 enhances neuronal NHE activity and results in increases in NE release. In contrast, exogenously ap-

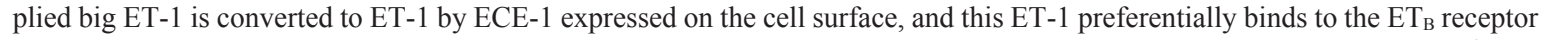
located on NOS-containing cells. As a result, increments in NO production cause inhibition of NE release. $\mathrm{NCX} \mathrm{Na}^{+} / \mathrm{Ca}^{2+} \mathrm{ex}^{-}$ changer, VMAT: vesicular monoamine transporter.

We also reported that exogenous big ET-1 suppressed ischemia/reperfusion-induced NE overflow and improved cardiac dysfunction observed after reperfusion, in spite of the fact that ET-1 content in coronary effluent from the heart exposed to ischemia/reperfusion was increased by exogenous big ET-1 application (59). In addition, treatment with big ET-1 in the presence of A-192621, a selective $\mathrm{ET}_{\mathrm{B}}$-receptor antagonist, failed to exert beneficial effects against ischemia/reperfusion-induced NE overflow and subsequent cardiac dysfunction. Thus, ET-1 generated from exogenously applied big ET-1 preferentially may act on $\mathrm{ET}_{\mathrm{B}}$ receptors rather than $\mathrm{ET}_{\mathrm{A}}$ receptors, leading to an increase in NO production and subsequent suppression of NE overflow (Fig. 2).
A study by Khamaisi et al. (60) has shown that ECE-1, a dominant subtype of ECE, colocalizes with the $\mathrm{ET}_{\mathrm{B}}$ receptor in the kidney. Accordingly, there is a possibility that ECE-1 and $\mathrm{ET}_{\mathrm{B}}$ receptors colocalize somewhere within cardiac tissues. If so, endogenously generated ET-1 should also act preferentially on $\mathrm{ET}_{\mathrm{B}}$ receptors. ECE-1 is classified into four isoforms by differences in subcellular distribution in rats (61). Emoto et al. described that the isoform cleaving big ET-1 was different between endogenously synthesized and exogenously supplied ones; endogenous big ET-1 may be cleaved by ECE-1a, which is located intracellularly, whereas exogenously applied big ET-1 may be cleaved by ECE-1b at cell surfaces (62). If ECE1b expressed on the cell surface is 
close to $\mathrm{ET}_{\mathrm{B}}$ receptors, it is a reasonable explanation as to why ET-1 produced by exogenous big ET-1 preferentially acts on $\mathrm{ET}_{\mathrm{B}}$ receptors but not on $\mathrm{ET}_{\mathrm{A}}$ receptors. However, further investigations are required to clarify this interesting hypothesis.

According to the results of animal and human studies, the therapeutic potential of ET-receptor antagonists in human heart failure had been tested in randomized clinical trials [REACH-1 (63) and ENABLE (M. Packer, unpublished data): bosentan, RITZ (64 - 67): tezosentan, HEAT (68) and EARTH (69): darusentan, ENCOR (70): enrasentan]. Most of these studies failed to demonstrate a clear improvement in the clinical status of patients (Table 1) and had to be stopped prematurely because of worsening of the disease or hepatic toxicity (71). Therefore, although these results cast doubt on the usefulness of ET-receptor antagonists for the treatment of myocardial infarction, the pathophysiological role of ET-1, as well as the potential benefit of ET-receptor antagonists, still needs to be investigated in cardiac diseases.

\subsection{Balloon angioplasty and neointimal formation}

Cardiovascular hypertrophy and remodeling are not simply a response to elevated blood pressure. Various vasoactive substances, such as angiotensin II, are implicated in the development of these structural changes (72).
ET-1 has potent mitogenic and hypertrophic properties, mainly via stimulation of $\mathrm{ET}_{\mathrm{A}}$ receptors (73). $\mathrm{ET}_{\mathrm{B}}$ receptor-mediated actions also protect against cardiovascular hypertrophy via endothelial NO generation, which inhibits mitogenesis and the proliferation of VSMCs (74).

Balloon angioplasty and stent insertion are now widely used for the treatment of coronary arterial disease. Although these procedures improve regional myocardial blood flow by dilating stenotic coronary vessels, one major drawback of this therapeutic approach is restenosis after the procedure because of the proliferation of VSMCs and neointimal formation triggered by mechanical damage to ECs. Several growth factors or vasoactive peptides are related to the process of neointimal formation. In a clinical study, expressions of ECE, ET-1, and ET receptors were enhanced in neointimal VSMCs after percutaneous coronary intervention in human coronary arteries (75). In addition, increases in ET-1 levels were observed in the coronary circulation after percutaneous transluminal coronary angioplasty (76). Anggrahini et al. recently demonstrated that ET-1 derived from ECs mainly contributes to the process of vascular remodeling in the model of flow cessation (10). Thus, ET-1 is closely related to the pathogenesis of restenosis after angioplasty. Similar results have been reported in animal models with restenosis such as balloon injury $(77,78)$. Murakoshi et

Table 1. Randomized clinical trials evaluating endothelin receptor antagonists in chronic heart failure

\begin{tabular}{|c|c|c|c|c|c|}
\hline $\begin{array}{l}\text { ETR antagonist } \\
\text { (selectivity) }\end{array}$ & Study & Patients & & Intervention & Outcome \\
\hline \multirow{2}{*}{$\begin{array}{l}\text { Bosentan } \\
\left(\mathrm{ET}_{\mathrm{A}} / \mathrm{ET}_{\mathrm{B}}\right)\end{array}$} & REACH-1 & $\mathrm{n}=370$ & $\begin{array}{l}\text { NYHA IIIb-IV } \\
\text { LVEF }<35 \%\end{array}$ & $500 \mathrm{mg}$, b.i.d., p.o. for 24 wk vs. placebo & No improvements in end points \\
\hline & $\begin{array}{l}\text { ENABLE I } \\
\text { ENABLE II }\end{array}$ & $\mathrm{n}=1613$ & $\begin{array}{l}\text { NYHA IIIb-IV } \\
\text { LVEF }<35 \%\end{array}$ & $\begin{array}{l}62.5 \mathrm{mg} \text {, b.i.d., p.o., for } 4 \text { wk increased } \\
\text { to } 125 \mathrm{mg} \text {, for an average of } 72 \mathrm{wk} \text { vs. placebo }\end{array}$ & No improvements in end points \\
\hline \multirow{4}{*}{$\begin{array}{l}\text { Tezosentan } \\
\left(\mathrm{ET}_{\mathrm{A}} / \mathrm{ET}_{\mathrm{B}}\right)\end{array}$} & RITZ-1 & $\mathrm{n}=675$ & ADHF & $50 \mathrm{mg} / \mathrm{h}$, i.v. for $24 \mathrm{~h}$ vs. placebo & No difference in all end points \\
\hline & RITZ-2 & $\mathrm{n}=292$ & ADHF & 50 or $100 \mathrm{mg} / \mathrm{h}$, i.v. for $24 \mathrm{~h}$ vs. placebo & $\begin{array}{l}\text { Both does produced similar increase } \\
\text { in cardiac index and fall in PCWP }\end{array}$ \\
\hline & RITZ-4 & $\mathrm{n}=193$ & ADHF with ACS & $\begin{array}{l}25 \mathrm{mg} / \mathrm{h} \text {, i.v. for } 1 \mathrm{~h} \text {, then } 50 \mathrm{mg} / \mathrm{h} \text {, i.v. } \\
\text { for } 23 \text { to } 47 \mathrm{~h} \text { vs. placebo }\end{array}$ & No difference in all end points \\
\hline & RITZ-5 & $\mathrm{n}=84$ & $\mathrm{ACHF}$ & 50 or $100 \mathrm{mg} / \mathrm{h}$, i.v. for $24 \mathrm{~h}$ vs. placebo & No improvements in end points \\
\hline \multirow{2}{*}{$\begin{array}{l}\text { Darusentan } \\
\left(\mathrm{ET}_{\mathrm{A}}\right)\end{array}$} & HEAT & $\mathrm{n}=157$ & $\begin{array}{l}\text { NYHA II } \\
\text { LVEF }<35 \%\end{array}$ & $\begin{array}{l}\text { 10, } 100,300 \mathrm{mg} / \text { day, p.o., for } 3 \mathrm{wk} \\
\text { vs. placebo }\end{array}$ & Improvement in cardiac index \\
\hline & EARTH & $\mathrm{n}=642$ & $\begin{array}{l}\text { NYHA II-IV } \\
\text { LVEF }<35 \%\end{array}$ & $\begin{array}{l}10,25,50,100,300 \mathrm{mg} / \text { day, p.o., for } 24 \mathrm{wk} \\
\text { vs. placebo }\end{array}$ & No difference in end points \\
\hline $\begin{array}{l}\text { Enrasentan } \\
\left(\mathrm{ET}_{\mathrm{A}} / \mathrm{ET}_{\mathrm{B}}\right)\end{array}$ & ENCOR & $\mathrm{n}=419$ & $\begin{array}{l}\text { NYHA II-III } \\
\text { LVEF }<35 \%\end{array}$ & $\begin{array}{l}\text { 30, 60, } 90 \mathrm{mg} \text { /day, p.o., for } 36 \mathrm{wk} \text { vs. enalapril } \\
10 \mathrm{mg} / \text { day, p.o., q.i.d. vs. placebo }\end{array}$ & Better outcome in placebo group \\
\hline
\end{tabular}

REACH-1: Research on Endothelin Antagonism in Chronic Heart Failure, ENABLE: Endothelin Antagonist Bosentan for Lowering Cardiac Events, RITZ: Randomized Intravenous TeZosentan, HEAT: Heart Failure ET[A] Receptor Blockade Trial, EARTH: Endothelin $n_{\mathrm{A}}$ Receptor Antagonist Trial in Heart Failure, ENCOR: ENrasentan COoperative Randomized, ETR: endothelin receptor, NYHA: New York Heart Association, ADHF: acute decompensated heart failure, ACS: acute coronary syndrome, ACHF: acute congestive heart failure, LVEF: left ventricular ejection fraction. 
al. showed that vascular remodeling caused by the cessation of blood flow was markedly accelerated in the carotid artery of $\mathrm{ET}_{\mathrm{B}}$ receptor-knockout mice, and long-term treatment with an $\mathrm{ET}_{\mathrm{B}}$-receptor antagonist worsened vascular remodeling in wild-type mice (6). In contrast, selective $\mathrm{ET}_{\mathrm{A}}$-receptor blockade could attenuate this vascular remodeling in the same animals. There has also been a report showing that ET-1 contributes to the remodeling of mesenteric resistance arteries in diabetes via activation of $\mathrm{ET}_{\mathrm{A}}$ receptors, and $\mathrm{ET}_{\mathrm{B}}$ receptor-mediated actions provide vasoprotective effects (79). Our previous report has demonstrated that vascular remodeling is markedly attenuated by treatment with a selective $\mathrm{ET}_{\mathrm{A}^{-}}$ receptor antagonist, whereas pharmacological blockade of $\mathrm{ET}_{\mathrm{B}}$ receptors aggravates neointimal hyperplasia after balloon injury (80). Treatment with an $\mathrm{ET}_{\mathrm{A}} / \mathrm{ET}_{\mathrm{B}}$ dual receptor antagonist also suppresses neointimal hyperplasia and the efficacy of treatment is comparable with that of a selective $\mathrm{ET}_{\mathrm{A}}$-receptor antagonist (80), thereby suggesting that the antagonism of $\mathrm{ET}_{\mathrm{B}}$ receptors does not seem to impair the positive effects of concomitant $\mathrm{ET}_{\mathrm{A}^{-}}$ receptor antagonism. Furthermore, we also confirmed similar results in $\mathrm{ET}_{\mathrm{B}}$-deficient rats. Therefore, antagonism of the ET-1 / $\mathrm{ET}_{\mathrm{A}}$ receptor pathway appears to be essential for preventing neointimal hyperplasia after balloon injury, irrespective of the presence of $\mathrm{ET}_{\mathrm{B}}$ receptormediated actions.

\subsection{Pulmonary hypertension}

The lungs are known to synthesize ET-1 and possess $\mathrm{ET}_{\mathrm{A}}$ and $\mathrm{ET}_{\mathrm{B}}$ receptors, both of which are involved in physiological and pathophysiological actions of ET-1 in the lung. In particular, endothelial $\mathrm{ET}_{\mathrm{B}}$ receptors in lungs are responsible for circulating ET-1 clearance, with close to $50 \%$ removal during pulmonary transit in humans (81).

Pulmonary hypertension is characterized by elevated pulmonary arterial pressure, pulmonary arterial remodeling, and right ventricular hypertrophy. ET-1 has been regarded as a major pathological formation and progression factor in pulmonary hypertension because there is a clear correlation between the severity of this disease and increases in the concentration of plasma ET-1 in patients who have primary and secondary pulmonary hypertension $(82,83)$. Both selective $\mathrm{ET}_{\mathrm{A}}$ - and nonselective $\mathrm{ET}_{\mathrm{A}} /$ $\mathrm{ET}_{\mathrm{B}}$-receptor antagonists are now widely available for the treatment of pulmonary hypertension at the clinical level $(84,85)$.

In monocrotaline (MCT)-treated pulmonary hypertensive rats, ET-1 concentrations are higher in their lung perfusate than that of control animals (86). In these rats, cardiac ET-1 mRNA expression and ET-1 peptide levels in heart and plasma are known to be elevated $(87,88)$. In addition, elevated ET-1 levels in right ventricular tissue are considered to be induced mainly by pressure overload to the heart rather than the primary causal factor of pulmonary hypertension (88); however, since ET-1 is a potent growth factor of myocardial cells (89), excess ET-1 production in right ventricular tissue seems to promote the progression of right ventricular hypertrophy in pulmonary hypertension. In fact, $\mathrm{ET}_{\mathrm{A}}$-receptor antagonism or $\mathrm{ET}_{\mathrm{A}} / \mathrm{ET}_{\mathrm{B}}$-receptor antagonism efficiently attenuated the progression of right ventricular hypertrophy and dysfunction in MCT-induced pulmonary hypertensive rats $(87,90-92)$.

Although the effectiveness of both selective $\mathrm{ET}_{\mathrm{A}^{-}}$and nonselective $\mathrm{ET}_{\mathrm{A}} / \mathrm{ET}_{\mathrm{B}}$-receptor antagonists has been demonstrated in human studies, as well as MCT-induced (87, 90-92) and hypoxic pulmonary hypertension $(92-94)$ in rats, it remains unclear as to which type of selective $\mathrm{ET}_{\mathrm{A}}$-receptor blockade or nonselective $\mathrm{ET}_{\mathrm{A}} /$ $\mathrm{ET}_{\mathrm{B}}$-receptor blockade is preferable. In other words, which receptor function of $\mathrm{ET}_{\mathrm{B} 1}$ involved in $\mathrm{NO}$ production and ET-1 clearance or $\mathrm{ET}_{\mathrm{B} 2}$ contributing to vascular contractile action should we pay attention to? A study by Nishida et al. (95) showed that blockade of the $\mathrm{ET}_{\mathrm{A}}$ receptor inhibited the pathological progression in MCTinduced pulmonary hypertensive rats, but the simultaneous suppression of the $\mathrm{ET}_{\mathrm{B}}$ receptor increased the $\mathrm{ET}_{\mathrm{A}}$-receptor antagonist actions. More specifically, combined dosing with an $\mathrm{ET}_{\mathrm{A}}$-receptor antagonist (ABT627) and $\mathrm{ET}_{\mathrm{B}}$-receptor antagonist (A-192621) exerted similar or more effective actions than that of ABT-627 single dosing against increases in right ventricular systolic pressure and right ventricular hypertrophy by MCT treatment. In addition, increases in the sensitivity of vascular contraction via $\mathrm{ET}_{\mathrm{A}}$ and $\mathrm{ET}_{\mathrm{B} 2}$ receptors and reductions in vascular relaxation via the $\mathrm{ET}_{\mathrm{B} 1}$ receptor were observed in the pulmonary vascular bed in this rat model. Furthermore, although pharmacological or genetic inhibition of the $\mathrm{ET}_{\mathrm{B}}$ receptor worsened MCT-induced pulmonary hypertension, ABT-627 completely suppressed this deterioration $(8,95)$. These findings suggest that an $\mathrm{ET}_{\mathrm{A}} / \mathrm{ET}_{\mathrm{B}}$-receptor antagonist brings reasonable validity by suppressing overactivation of the $\mathrm{ET}-1 / \mathrm{ET}_{\mathrm{A}}$ receptor system and vasoconstriction via the $\mathrm{ET}_{\mathrm{B} 2}$ receptor. Moreover, it is less likely that the $\mathrm{ET}_{\mathrm{B} 1}$ receptor actively functions as a protective factor through increases in $\mathrm{NO}$ production.

\subsection{Salt-sensitive hypertension}

Previous studies, including ours, have demonstrated elevations in ET-1 content and ET-1 mRNA expression in vascular tissues of deoxycorticosterone acetate (DOCA)-salt hypertensive rats (96-98) and Dahl saltsensitive rats (99). Long-term treatment with selective 
$\mathrm{ET}_{\mathrm{A}}$-receptor antagonists or nonselective $\mathrm{ET}_{\mathrm{A}} / \mathrm{ET}_{\mathrm{B}}-$ receptor antagonists prevented DOCA-salt-induced hypertension and related tissue injuries, such as vascular hypertrophy, in a qualitatively similar fashion $(100-102)$. Although it is unknown which type of antagonist is favorable for the treatment of these hypertensive models, there is general agreement that $\mathrm{ET}_{\mathrm{A}}$ receptor-mediated actions play an important role in the development of saltdependent hypertension and associated tissue injury. On the other hand, we reported that chronic treatment of DOCA-salt rats with A-192621, an orally active and highly potent $\mathrm{ET}_{\mathrm{B}}$-selective receptor antagonist, led to exaggerated deterioration of cardiovascular and renal injuries (102). Other studies using salt-loaded rats also showed that chronic $\mathrm{ET}_{\mathrm{B}}$-receptor blockade indirectly caused activation of the ET-1 / $\mathrm{ET}_{\mathrm{A}}$ receptor system followed by increases in blood pressure, thereby suggesting that blockade of the $\mathrm{ET}_{\mathrm{B}}$ receptor was harmful in saltsensitive hypertension (103). In addition, the hypertensive effect induced by an intravenous bolus injection of the selective $\mathrm{ET}_{\mathrm{B}}$-receptor antagonist Ro 46-8443 in DOCA-salt rats was greater than that in uninephrectomized control rats (104). Renal vasoconstrictor effects induced by the selective $\mathrm{ET}_{\mathrm{B}}$-receptor antagonist $\mathrm{BQ}-788$ were also enhanced in DOCA-salt hypertensive rats (105). Our previous study also demonstrated that rats with genetic $\mathrm{ET}_{\mathrm{B}}$ deficiency clearly exhibited exaggerated blood pressure sensitivity to DOCA-salt treatment over that in wild-type rats (5). $\mathrm{ET}_{\mathrm{B}}$-deficient rats had enhanced vascular hypertrophy, worsening of renal dysfunction, and tissue damage after DOCA-salt treatment. These changes seen in $\mathrm{ET}_{\mathrm{B}}$-deficient rats were markedly suppressed by the daily administration of ABT-627, a potent $\mathrm{ET}_{\mathrm{A}}$-selective receptor antagonist (5). Furthermore, Elmarakby et al. reported that an $\mathrm{ET}_{\mathrm{A}}$-receptor antagonist attenuated salt-induced hypertension and vascular superoxide production in genetic $\mathrm{ET}_{\mathrm{B}}$ deficiency (7). Taken together, $\mathrm{ET}_{\mathrm{B}}$ receptor-mediated actions are protective in the pathogenesis of salt-sensitive hypertension. These results also suggest that the antagonism of the $\mathrm{ET}_{\mathrm{A}}$ receptor is essential for protection from cardiovascular disease including salt-sensitive hypertension, irrespective of the presence of the $\mathrm{ET}_{\mathrm{B}}$ receptor. This view may explain the findings that selective $\mathrm{ET}_{\mathrm{A}}$-receptor antagonists and nonselective $\mathrm{ET}_{\mathrm{A}} / \mathrm{ET}_{\mathrm{B}}$-receptor antagonists similarly improve salt-sensitive hypertension and related tissue injuries.

\subsection{Sex differences in CVD}

Clinical and epidemiological evidence suggests a sexually dimorphic pattern of atherosclerotic CVD in humans. The incidence of CVD is lower in women before menopause than in men and postmenopausal women (106,
107). These sex differences are considered to be caused by the vasoprotective effect of estrogen $(108-110)$. In fact, several clinical studies showed that postmenopausal women who receive estrogen replacement therapy (ERT) have a substantially lower risk of incidence of cardiovascular disease $(111,112)$. The protective effect of estrogen on the cardiovascular system is closely related to the up-regulation of endothelial NO production and downregulation of adhesion molecule activity, smooth muscle proliferation/migration, and superoxide production $(113-115)$. However, recent clinical trials produced different results. The Heart Estrogen-Progestin Replacement Study (HERS) and Women's Health Initiative Clinical Trial and observational study (WHI) did not show any benefit of ERT $(116,117)$. Thus, the effects of ERT on cardiovascular disease are still controversial. Determinations of the mechanisms of estrogen-exhibited vasoprotective effects and alternative therapies of estrogen in postmenopausal women remain a critical issue.

Substantial evidence indicates that gonadal hormones, especially $17 \beta$-estradiol, modulate the ET system. $17 \beta$-Estradiol inhibits both basal and cytokine-induced ET-1 production at the transcriptional level $(118,119)$. Vascular functional ECE activity is also affected by $17 \beta$-estradiol (120). In addition, several clinical studies have reported that plasma ET-1 concentrations are lower in women than men $(121-123)$. Plasma ET-1 concentrations in women fluctuate during the menstrual cycle (124) and pregnancy (125). Healthy older women exhibit higher plasma ET-1 levels than those of healthy young or middle-aged women. Hormone replacement therapy (17 $\beta$-estradiol plus methoxyprogesterone) in healthy postmenopausal women results in decrease in plasma ET-1 levels (122). Furthermore, an investigation of cross-gender hormone treatment indicated that plasma ET-1 levels in male-to-female transsexual patients were decreased (126). Taken together, it is reasonable to assume that $17 \beta$-estradiol is mainly involved in sex differences in the ET system.

Sex differences in ET-receptor density, as well as in the ratio of ET-receptor subtypes, have been also investigated. Ergul et al. reported that men's saphenous veins have a larger number of ET receptors and an increased ratio of $\mathrm{ET}_{\mathrm{A}}$ to $\mathrm{ET}_{\mathrm{B}}$ receptors compared to women's saphenous veins and that these differences were reflected by the sex differences in ET-1-induced vascular contractile responses (127). On the other hand, although several animal studies also indicated that ET receptors are involved in the sex differences in the incidence of CVD, the effect of estrogen on these receptors is quite contradictory. For example, Nuedling et al. demonstrated upregulation of the $\mathrm{ET}_{\mathrm{B}}$ receptor in the heart of ovariectomized female spontaneously hypertensive rats, which 
could be reversed by exogenous estrogen replacement (128). They also confirmed downregulation of the $\mathrm{ET}_{\mathrm{B}}$ receptor by $17 \beta$-estradiol in cultured cardiomyocytes. Others reported similar results showing that vascular mRNA expression of $\mathrm{ET}_{\mathrm{B}}$, but not $\mathrm{ET}_{\mathrm{A}}$ receptors in DOCA-salt-induced hypertensive rats was higher in males than that observed in females $(129,130)$. In contrast, Pedersen et al. showed that $17 \beta$-estradiol treatment reduced levels of the $\mathrm{ET}_{\mathrm{A}}$, but not the $\mathrm{ET}_{\mathrm{B}}$ receptor in the rabbit thoracic aorta and epicardial arteries (131). However, their previous study indicated that $17 \beta$-estradiol induced up-regulation of $\mathrm{ET}_{\mathrm{B}}$-receptor gene expression in coronary arteries from ovariectomized hyperlipidemic rabbits (132). Thus, estrogen may cause differential effects on vascular ET receptors in different species and/or vascular beds.

Our previous study demonstrated that the frequency of neointimal formation after balloon injury was much lower in females than in males and that neointimal formation after vascular injury in female rats was significantly aggravated by ovariectomy, and this aggravation was markedly improved by $17 \beta$-estradiol treatment (133). These results clearly indicate that estrogen inhibits neointimal formation after vascular injury in female rats. Furthermore, this sex difference in neointimal formation was abolished by genetic $\mathrm{ET}_{\mathrm{B}}$-receptor deficiency or pharmacological $\mathrm{ET}_{\mathrm{B}}$-receptor blockade. Both ovariectomy and ovariectomy plus $17 \beta$-estradiol treatment failed to affect the enhanced neointimal formation observed in intact female $\mathrm{ET}_{\mathrm{B}}$-deficient rats. In other words, as the vasoprotective effects of estrogen after vascular injury were abolished by genetic deficiencies in the $\mathrm{ET}_{\mathrm{B}}$ receptor, estrogen likely reduces neointimal formation after vascular injury via a mechanism that depends on $\mathrm{ET}_{\mathrm{B}}$ receptor-mediated actions. These findings suggest that $\mathrm{ET}_{\mathrm{B}}$ receptor-mediated actions seem to occur downstream of the vasoprotective effects of estrogen, although the relationship between $\mathrm{ET}_{\mathrm{B}}$ receptor- and estrogen receptor-signaling systems remains unclear. On the other hand, neointimal hyperplasia observed in female $\mathrm{ET}_{\mathrm{B}^{-}}$ deficient rats is almost completely suppressed by $\mathrm{ET}_{\mathrm{A}}$ or $\mathrm{ET}_{\mathrm{A}} / \mathrm{ET}_{\mathrm{B}}$-receptor antagonists. Thus, augmentation of $\mathrm{ET}_{\mathrm{A}}$ receptor-mediated actions under $\mathrm{ET}_{\mathrm{B}}$-receptor dysfunction seems to be responsible for the abolition of sex differences in vascular remodeling.

\section{Conclusion}

Since the discovery of ET-1, many researchers have elucidated the physiological and pathophysiological role of ET-1 and ET receptors in the cardiovascular system over the past 20 years. Among many non-peptide and orally available ET-receptor antagonists developed so far, the nonselective $\mathrm{ET}_{\mathrm{A}} / \mathrm{ET}_{\mathrm{B}}$-receptor antagonist bosentan and selective $\mathrm{ET}_{\mathrm{A}}$-receptor antagonist ambrisentan are now clinically utilized as agents for pulmonary artery hypertension. There is a possibility that ambrisentan could be widely used in the treatment of pulmonary hypertension because of less interactions with other drugs or side effects such as liver dysfunction. In addition, future clinical applications may provide new findings about which antagonist is more effective, a nonselective $\mathrm{ET}_{\mathrm{A}} /$ $\mathrm{ET}_{\mathrm{B}}$-receptor or selective $\mathrm{ET}_{\mathrm{A}}$-receptor antagonist. On the other hand, although the selective $\mathrm{ET}_{\mathrm{A}}$-receptor antagonist sitaxsentan, which was released in Europe and the United States, was recently forced to be withdrawn because of a high risk of liver failure, it is hoped in the future that other ET-receptor antagonists, including macitentan and zibotentan, currently being developed can be utilized in clinical treatment targeted at the cardiovascular ET-1 system.

\section{References}

1 Yanagisawa M, Kurihara H, Kimura S, Tomobe Y, Kobayashi M, Mitsui Y, et al. A novel potent vasoconstrictor peptide produced by vascular endothelial cells. Nature. 1988;332:411-415.

2 Levin ER. Endothelins as cardiovascular peptides. Am J Nephrol. 1996;16:246-251.

3 Rich S, McLaughlin VV. Endothelin receptor blockers in cardiovascular disease. Circulation. 2003;108:2184-2190.

4 Agapitov AV, Haynes WG. Role of endothelin in cardiovascular disease. J Renin Angiotensin Aldosterone Syst. 2002;3:1-15.

5 Matsumura Y, Kuro T, Kobayashi Y, Konishi F, Takaoka M, Wessale JL, et al. Exaggerated vascular and renal pathology in endothelin-B receptor-deficient rats with deoxycorticosterone acetate-salt hypertension. Circulation. 2000;102:2765-2773.

6 Murakoshi N, Miyauchi T, Kakinuma Y, Ohuchi T, Goto K, Yanagisawa $\mathrm{M}$, et al. Vascular endothelin-B receptor system in vivo plays a favorable inhibitory role in vascular remodeling after injury revealed by endothelin-B receptor-knockout mice. Circulation. 2002;106:1991-1998.

7 Elmarakby AA, Dabbs Loomis E, Pollock JS, Pollock DM. ET receptor blockade attenuates hypertension and decreases reactive oxygen species in $\mathrm{ET}_{\mathrm{B}}$ receptor-deficient rats. J Cardiovasc Pharmacol. 2004;44:S7-S10.

8 Nishida M, Okada Y, Akiyoshi K, Eshiro K, Takoaka M, Gariepy $\mathrm{CE}$, et al. Role of endothelin $\mathrm{ET}_{\mathrm{B}}$ receptor in the pathogenesis of monocrotaline-induced pulmonary hypertension in rats. Eur $\mathrm{J}$ Pharmacol. 2004;496:159-165.

9 Yamamoto S, Matsumoto N, Kanazawa M, Fujita M, Takaoka M, Gariepy CE, et al. Differential contributions of endothelin-A and endothelin-B receptors in postischemic cardiac dysfunction and norepinephrine overflow in rat hearts. Circulation. 2005;111: 302-309.

10 Anggrahini DW, Emoto N, Nakayama K, Widyantoro B, Adiarto $\mathrm{S}$, Iwasa N, et al. Vascular endothelial cell-derived endothelin-1 mediates vascular inflammation and neointima formation following blood flow cessation. Cardiovasc Res. 2009;82:143-151.

11 Nunez DJR, Brown MJ, Davenport AP, Neylon CB, Schofield JP, 
Wyse RK. Endothelin-1 messenger-RNA is widely expressed in porcine and human tissues. J Clin Invest. 1990;85:1537-1541.

12 Resink TJ, Hahn AWA, Scott-Burden T, Powell J, Weber E, Buhler FR. Inducible endothelin messenger RNA expression and peptide secretion in cultured human vascular smooth muscle cells. Biochem Biophys Res Commun. 1990;168:1303-1310.

13 Firth JD, Ratcliffe PJ. Organ distribution of the 3 rat endothelin messenger RNAs and the effects of ischemia on renal gene expression. J Clin Invest. 1992;90:1023-1031.

14 Wilson DB, Dorfman DM, Orkin SH. A nonerythroid GATAbinding protein is required for function of the human preproendothelin-1 promoter in endothelial cells. Mol Cell Biol. 1990; 10:4854-4862.

$15 \mathrm{Hu}$ J, Discher DJ, Bishopric NH, Webster KA. Hypoxia regulates expression of the endothelin-1 gene through a proximal hypoxiainducible factor-1 binding site on the antisense strand. Biochem Biophys Res Commun. 1998;245:894-899.

16 Rodriguez-Pascual F, Redondo-Horcajo M, Lamas S. Functional cooperation between Smad proteins and activator protein-1 regulates transforming growth factor- $\beta$-mediated induction of endothelin-1 expression. Circ Res. 2003;92:1288-1295.

17 Quehenberger P, Bierhaus A, Fasching P, Muellner C, Klevesath $\mathrm{M}$, Hong $\mathrm{M}$, et al. Endothelin 1 transcription is controlled by nuclear factor $\kappa \mathrm{B}$ in AGE-stimulated cultured endothelial cells. Diabetes. 2000;49:1561-1570.

18 Wort SJ, Ito M, Chou PC, Mc Master SK, Badiger R, Jazrawi E, et al. Synergistic induction of endothelin-1 by tumor necrosis factor a and interferon $\gamma$ is due to enhanced NF- $\kappa \mathrm{B}$ binding and histone acetylation at specific $\kappa \mathrm{B}$ sites. J Biol Chem. 2009; 284:24297-24305.

19 Fukuroda T, Fujikawa T, Ozaki S, Ishikawa K, Yano M, Nishikibe M. Clearance of circulating endothelin-1 by $\mathrm{ET}_{\mathrm{B}}$ receptors in rats. Biochem Biophys Res Commun. 1994;199:1461-1465.

20 Dupuis J, Goresky CA, Fournier A. Pulmonary clearance of circulating endothelin-1 in dogs in vivo: exclusive role of $\mathrm{ET}_{\mathrm{B}}$ receptors. J Appl Physiol. 1996;81:1510-1515.

21 Dupuis J, Schwab AJ, Simard A, Cernacek P, Stewart DJ, Goresky CA. Kinetics of endothelin-1 binding in the dog liver microcirculation in vivo. Am J Physiol. 1999;277:G905-G914.

22 Tran Duc AT, Schwab AJ, Simard A, Villeneuve L, Dupuis J. Reduction in hepatic endothelin-1 clearance in cirrhosis. Clin Sci (Lond). 2003;105:227-234.

23 Johnström P, Fryer TD, Richards HK, Harris NG, Barret O, Clark $\mathrm{JC}$, et al. Positron emission tomography using ${ }^{18} \mathrm{~F}$-labelled endothelin-1 reveals prevention of binding to cardiac receptors owing to tissue-specific clearance by $\mathrm{ET}_{\mathrm{B}}$ receptors in vivo. $\mathrm{Br} \mathrm{J}$ Pharmacol. 2005;144:115-122.

24 Iwasa S, Fan J, Shimokama T, Nagata M, Watanabe T. Increased immunoreactivity of endothelin-1 and endothelin B receptor in human atherosclerotic lesions. A possible role in atherogenesis. Atherosclerosis. 1999;146:93-100.

25 Cardillo C, Kilcoyne CM, Waclawiw M, Cannon RO 3rd, Panza JA. Role of endothelin in the increased vascular tone of patients with essential hypertension. Hypertension. 1999;33:753-758.

26 Dimitrijevic I, Edvinsson ML, Chen Q, Malmsjö M, Kimblad PO, Edvinsson L. Increased expression of vascular endothelin type $\mathrm{B}$ and angiotensin type 1 receptors in patients with ischemic heart disease. BMC Cardiovasc Disord. 2009;9:40.

27 Bourque SL, Davidge ST, Adams MA. The interaction between endothelin-1 and nitric oxide in the vasculature: new perspec- tives. Am J Physiol Regul Integr Comp Physiol. 2011;300: R1288-R1295.

28 Liu S, Premont RT, Kontos CD, Huang J, Rockey DC. Endothelin-1 activates endothelial cell nitric-oxide synthase via heterotrimeric G-protein $\beta \gamma$ subunit signaling to protein kinase B/Akt. J Biol Chem. 2003;278:49929-49935.

29 Wedgwood S, Black SM. Endothelin-1 decreases endothelial NOS expression and activity through $\mathrm{ET}_{\mathrm{A}}$ receptor-mediated generation of hydrogen peroxide. Am J Physiol Lung Cell Mol Physiol. 2005;288:L480-L487.

30 Matsuyama K, Yasue H, Okumura K, Saito Y, Nakao K, Shirakami G, et al. Increased plasma level of endothelin-1-like immunoreactivity during coronary spasm in patients with coronary spastic angina. Am J Cardiol. 1991;68:991-995.

31 Miyauchi T, Yanagisawa M, Tomizawa T, Sugishita Y, Suzuki N, Fujino M, et al. Increased plasma concentrations of endothelin-1 and big endothelin-1 in acute myocardial infarction. Lancet. 1989;2:53-54.

32 Malatino LS, Grassi R, Stancanelli B. Release of immunoreactive endothelin from the heart during percutaneous transluminal coronary angioplasty. Am Heart J. 1993;126:700-702.

33 Brunner F, DuToit EF, Opie LH. Endothelin release during ischaemia and reperfusion of isolated perfused rat hearts. J Mol Cell Cardiol. 1992;24:1291-1305.

34 Hasdai D, Kornowski R, Battler A. Endothelin and myocardial ischemia. Cardiovasc Drugs Ther. 1994;8:589-599.

35 Bugge E, Ytrehus K. Endothelin-1 can reduce infarct size through protein kinase $\mathrm{C}$ and $\mathrm{K}_{\mathrm{ATP}}$ channels in the isolated rat heart. Cardiovasc Res. 1996;32:920-929.

36 Wang P, Gallagher KP, Downey JM, Cohen MV. Pretreatment with endothelin-1 mimics ischemic preconditioning against infarction in isolated rabbit heart. J Mol Cell Cardiol. 1996;28: 579-588.

37 Hide EJ, Piper J, Thiemermann C. Endothelin-1-induced reduction of myocardial infarct size by activation of ATP-sensitive potassium channels in a rabbit model of myocardial ischaemia and reperfusion. Br J Pharmacol. 1995;116:2597-2602.

38 Gourine AV, Molosh AI, Poputnikov D, Bulhak A, Sjöquist PO, Pernow J. Endothelin-1 exerts a preconditioning-like cardioprotective effect against ischaemia/reperfusion injury via the $\mathrm{ET}_{\mathrm{A}}$ receptor and the mitochondrial $\mathrm{K}_{\mathrm{ATP}}$ channel in the rat in vivo. $\mathrm{Br}$ J Pharmacol. 2005;144:331-337.

39 Brunner F, Opie LH. Role of endothelin-A receptors in ischemic contracture and reperfusion injury. Circulation. 1998;97: 391-398.

40 Galiuto L, DeMaria AN, Del Balzo U, May-Newman K, Flaim SF, Wolf PL, et al. Ischemia-reperfusion injury at the microvascular level: treatment by endothelin A-selective antagonist and evaluation by myocardial contrast echocardiography. Circulation. 2000;102:3111-3116.

41 Pernow J, Wang QD. Endothelin in myocardial ischaemia and reperfusion. Cardiovasc Res. 1997;33:518-526.

42 Reriani M, Raichlin E, Prasad A, Mathew V, Pumper GM, Nelson RE, et al. Long-term administration of endothelin receptor antagonist improves coronary endothelial function in patients with early atherosclerosis. Circulation. 2010;122:958-966.

43 Intengan HD, Schiffrin EL. Vascular remodeling in hypertension: roles of apoptosis, inflammation, and fibrosis. Hypertension. 2001;38:581-587.

44 Callera GE, Montezano AC, Touyz RM, Zorn TM, Carvalho 
MH, Fortes ZB, et al. ETA receptor mediates altered leukocyteendothelial cell interaction and adhesion molecules expression in DOCA-salt rats. Hypertension. 2004;43:872-879.

45 Braunwald E, Sobel BE. Coronary blood flow and myocardial ischemia. In: Braunwald, E, editor. Heart disease, a textbook of cardiovascular medicine. Philadelphia: WB Saunders; 1988. p. 1191-1221.

46 Schömig A, Haass M, Richardt G. Catecholamine release and arrhythmias in acute myocardial ischemia. Eur Heart J. 1991; 12 Suppl F:38-47.

47 Isaka M, Kudo A, Imamura M, Kawakami H, Yasuda K. Endothelin receptors, localized in sympathetic nerve terminals of the heart, modulate norepinephrine release and reperfusion arrhythmias. Basic Res Cardiol. 2007;102:154-162.

48 Oikonomidis DL, Tsalikakis DG, Baltogiannis GG, Tzallas AT, Xourgia X, Agelaki MG, et al. Endothelin-B receptors and ventricular arrhythmogenesis in the rat model of acute myocardial infarction. Basic Res Cardiol. 2010;105:235-245.

49 Crockett TR, Gray GA, Kane KA, Wainwright CL. Sarafotoxin $6 c(\mathrm{~S} 6 \mathrm{c})$ reduces infarct size and preserves mRNA for the $\mathrm{ET}_{\mathrm{B}}$ receptor in the ischemic/reperfused myocardium of anesthetized rats. J Cardiovasc Pharmacol. 2004;44:148-154.

50 Giannessi D, Del Ry S, Vitale RL. The role of endothelins and their receptors in heart failure. Pharmacol Res. 2001;43: 111-126.

51 Bohnemeier H, Pinto YM, Horkay F, Tóth M, Juhász-nagy A, Orzechowski HD, et al. Endothelin converting-enzyme-1 mRNA expression in human cardiovascular disease. Clin Exp Hypertens. 1998;20:417-437.

52 Umekawa K, Hasegawa H, Tsutsumi Y, Sato K, Matsumura Y, Ohashi N. Pharmacological characterization of a novel sulfonylureid-pyrazole derivative, SM-19712, a potent nonpeptidic inhibitor of endothelin converting enzyme. Jpn J Pharmacol. 2000;84:7-15.

53 Martin P, Tzanidis A, Stein-Oakley A, Krum H. Effect of a highly selective endothelin-converting enzyme inhibitor on cardiac remodeling in rats after myocardial infarction. J Cardiovasc Pharmacol. 2000;36 Suppl 1:S367-S370.

54 Matsumura Y, Hisaki K, Takaoka M, Morimoto S. Phosphoramidon, a metalloproteinase inhibitor, suppresses the hypertensive effect of big endothelin-1. Eur J Pharmacol. 1990;185:103-106.

55 Trapani AJ, De Lombaert S, Kuzmich S, Jeng AY. Inhibition of big ET-1-induced pressor response by an orally active dual inhibitor of endothelin-converting enzyme and neutral endopeptidase 24.11. J Cardiovasc Pharmacol. 1995;26:S69-S71.

56 Fecteau MH, Honoré JC, Plante M, Labonté J, Rae GA, D’Orléans-Juste P. Endothelin-1 (1-31) is an intermediate in the production of endothelin-1 after big endothelin-1 administration in vivo. Hypertension. 2005;46:87-92.

57 Grover GJ, Sleph PG, Fox M, Trippodo NC. Role of endothelin-1 and big endothelin-1 in modulating coronary vascular tone, contractile function and severity of ischemia in rat hearts. J Pharmacol Exp Ther. 1992;263:1074-1082.

58 Sharif I, Kane KA, Wainwright CL. Endothelin and ischaemic arrhythmias-antiarrhythmic or arrhythmogenic? Cardiovasc Res. 1998;39:625-632.

59 Tawa M, Fukumoto T, Ohkita M, Yamashita N, Geddawy A, Imamura T, et al. Effects of exogenous big endothelin-1 on postischemic cardiac dysfunction and norepinephrine overflow in rat hearts. Hypertens Res. 2011;34:218-224.
60 Khamaisi M, Raz I, Shilo V, Rosenberger C, Dahan R, Abassi Z, et al. Diabetes and radiocontrast media increase endothelin converting enzyme-1 in the kidney. Kidney Int. 2008;74:91-100.

61 Valdenaire O, Lepailleur-Enouf D, Egidy G, Thouard A, Barret A, Vranckx R, et al. A fourth isoform of endothelin-converting enzyme (ECE-1) is generated from an additional promoter. Eur J Biochem. 1999;264:341-349.

62 Emoto N, Nurhantari Y, Alimsardjono H, Xie J, Yamada T, Yanagisawa $\mathrm{M}$, et al. Constitutive lysosomal targeting and degradation of bovine endothelin-converting enzyme-1a mediated by novel signals in its alternatively spliced cytoplasmic tail. J Biol Chem. 1999;274:1509-1518.

63 Packer M. Multicentre, double-blind, placebo-controlled study of long-term endothelin blockade with bosentan in chronic heart failure - results of the REACH-1 trial [Abstract]. Circulation. 1998;98:I-3.

64 Teerlink JR, Massie B, Cleland J, Tzivoni D, for the RITZ-1 Investigators. A double-blind, parallel-group, multi-center, placebocontrolled study to investigate the efficacy and safety of tezosentan in reducing symptoms in patients with acute decompensated heart failure [Abstract]. Circulation. 2001;104:II-526.

65 Torre-Amione G, Young JB, Colucci WS, Lewis BS, Pratt C, Cotter G, et al. Hemodynamic and clinical effects of tezosentan, an intravenous dual endothelin receptor antagonist, in patients hospitalized for acute decompensated heart failure. J Am Coll Cardiol. 2003;42:140-147.

66 O'Connor CM, Gattis WA, Adams KF Jr, Hasselblad V, Chandler B, Frey A, et al. Randomized Intravenous Tezosentan Study-4 Investigators. Tezosentan in patients with acute heart failure and acute coronary syndromes: results of the Randomized Intravenous TeZosentan Study (RITZ-4). J Am Coll Cardiol. 2003; 41:1452-1457.

67 Kaluski E, Kobrin I, Zimlichman R, Marmor A, Krakov O, Milo $\mathrm{O}$, et al. RITZ-5: randomized intravenous Tezosentan (an endothelin-A/B antagonist) for the treatment of pulmonary edema: a prospective, multicenter, double-blind, placebo-controlled study. J Am Coll Cardiol. 2003;41:204-210.

68 Lüscher TF, Enseleit F, Pacher R, Mitrovic V, Schulze MR, Willenbrock R, et al. Hemodynamic and neurohumoral effects of selective endothelin A (ET(A)) receptor blockade in chronic heart failure: the Heart Failure ET(A) Receptor Blockade Trial (HEAT). Circulation. 2002;106:2666-2672.

69 Anand I, McMurray J, Cohn JN, Konstam MA, Notter T, Quitzau $\mathrm{K}$, et al. Long-term effects of darusentan on left-ventricular remodelling and clinical outcomes in the Endothelin A Receptor Antagonist Trial in Heart Failure (EARTH): randomised, doubleblind, placebo-controlled trial. Lancet. 2004;364:347-354.

70 Abraham WT, Ascheim D, Demarco T, Klapholz M, Kukin M, Miller A, et al. Effects of enrasentan, a non selective endothelin receptor antagonist, in class II to III heart failure: results of the Enrasentan Cooperative Randomized (ENCOR) Evaluation [Abstract]. J Am Coll Cardiol. 2001;38:612.

71 Battistini B, Berthiaume N, Kelland NF, Webb DJ, Kohan DE. Profile of past and current clinical trials involving endothelin receptor antagonists: the novel "-sentan" class of drug. Exp Biol Med. 2006;231:653-695.

72 Gibbons GH, Dzau VJ. The emerging concept of vascular remodeling. N Engl J Med. 1994;330:1431-1438.

73 Ohlstein EH, Arleth A, Bryan H, Elliott JD, Sung CP. The selective endothelin $\mathrm{ET}_{\mathrm{A}}$ receptor antagonist $\mathrm{BQ} 123$ antagonizes en- 
dothelin-1-mediated mitogenesis. Eur J Pharmacol. 1992;225: 347-350.

74 Garg UC, Hassid A. Nitric oxide-generating vasodilators and 8-bromo-cyclic guanosine monophosphate inhibit mitogenesis and proliferation of cultured rat vascular smooth muscle cells. J Clin Invest. 1989;83:1774-1777.

75 Shirai N, Naruko T, Ohsawa M, Ikura Y, Sugama Y, Hirayama M, et al. Expression of endothelin-converting enzyme, endothelin-1 and endothelin receptors at the site of percutaneous coronary intervention in humans. J Hypertens. 2006;24:711-721.

76 Takase H, Sugiyama M, Nakazawa A, Toriyama T, Hayashi K, Goto $\mathrm{T}$, et al. Increased endogenous endothelin-1 in coronary circulation is associated with restenosis after coronary angioplasty. Can J Cardiol. 2003;19:902-906.

77 Douglas SA, Louden C, Vickery-Clark LM, Storer BL, Hart T, Feuerstein GZ, et al. A role for endogenous endothelin-1 in neointimal formation after rat carotid artery balloon angioplasty. Protective effects of the novel nonpeptide endothelin receptor antagonist SB 209670. Circ Res. 1994;75:190-197.

78 Wang X, Douglas SA, Louden C, Vickery-Clark LM, Feuerstein GZ, Ohlstein EH. Expression of endothelin-1, endothelin-3, endothelin-converting enzyme-1, and endothelin-A and endothelin$\mathrm{B}$ receptor mRNA after angioplasty-induced neointimal formation in the rat. Circ Res. 1996;78:322-328.

79 Sachidanandam K, Portik-Dobos V, Harris AK, Hutchinson JR, Muller E, Johnson MH, et al. Evidence for vasculoprotective effects of $\mathrm{ET}_{\mathrm{B}}$ receptors in resistance artery remodeling in diabetes. Diabetes. 2007;56:2753-2758.

80 Kitada K, Yui N, Matsumoto C, Mori T, Ohkita M, Matsumura Y. Inhibition of endothelin $\mathrm{ET}_{\mathrm{B}}$ receptor system aggravates neointimal hyperplasia after balloon injury of rat carotid artery. J Pharmacol Exp Ther. 2009;331:998-1004.

81 Dupuis J, Stewart DJ, Cernacek P, Gosselin G. Human pulmonary circulation is an important site for both clearance and production of endothelin-1. Circulation. 1996;94:1578-1584.

82 Stewart DJ, Levy R, Cernacek P, Langleben D. Increased plasma endothelin-1 in pulmonary hypertension: marker or mediator of disease? Ann Intern Med. 1991;114:464-469.

83 Cody RJ, Haas GJ, Binkley PF, Capers Q, Kelley R. Plasma endothelin correlates with the extent of pulmonary hypertension in patients with chronic congestive heart failure. Circulation. 1992;85:504-509.

84 Iglarz M, Clozel M. At the heart of tissue: endothelin system and end-organ damage. Clin Sci. 2010;119:453-463.

85 Shao D, Park JE, Wort SJ. The role of endothelin-1 in the pathogenesis of pulmonary arterial hypertension. Pharmacol Res. 2011;63:504-511.

86 Frasch HF, Marshall C, Marshall BE. Endothelin-1 is elevated in monocrotaline pulmonary hypertension. Am J Physiol. 1999; 276:L304-L310.

87 Miyauchi T, Yorikane R, Sakai S, Sakurai T, Okada M, Nishikibe $\mathrm{M}$, et al. Contribution of endogenous endothelin-1 to the progression of cardiopulmonary alterations in rats with monocrotalineinduced pulmonary hypertension. Circ Res. 1993;73:887-897.

88 Jasmin JF, Cernacek P, Dupuis J. Activation of the right ventricular endothelin (ET) system in the monocrotaline model of pulmonary hypertension: response to chronic $\mathrm{ET}_{\mathrm{A}}$ receptor blockade. Clin Sci. 2003;105:647-653.

89 Shubeita HE, McDonough PM, Harris AN, Knowlton KU, Glembotski CC, Brown JH, et al. Endothelin induction of inositol phospholipid hydrolysis, sarcomere assembly, and cardiac gene expression in ventricular myocytes. J Biol Chem. 1990;265: 20555-20562.

90 Hill NS, Warburton RR, Pietras L, Klinger JR. Nonspecific endothelin-receptor antagonist blunts monocrotaline-induced pulmonary hypertension in rats. J Appl Physiol. 1997;83: 1209-1215.

91 Jasmin JF, Lucas M, Cernacek P, Dupuis J. Effectiveness of a nonselective $\mathrm{ET}_{\mathrm{A} / \mathrm{B}}$ and a selective $\mathrm{ET}_{\mathrm{A}}$ antagonist in rats with monocrotaline-induced pulmonary hypertension. Circulation. 2001;103:314-318.

92 Tilton RG, Munsch CL, Sherwood SJ, Chen SJ, Chen YF, Wu C, et al. Attenuation of pulmonary vascular hypertension and cardiac hypertrophy with sitaxsentan sodium, an orally active ET(A) receptor antagonist. Pulm Pharmacol Ther. 2000;13:87-97.

93 Bonvallet ST, Zamora MR, Hasunuma K, Sato K, Hanasato N, Anderson D, et al. BQ123, an ETA-receptor antagonist, attenuates hypoxic pulmonary hypertension in rats. Am J Physiol. 1994;266:H1327-H1331.

94 Sato K, Morio Y, Morris KG, Rodman DM, McMurtry IF. Mechanism of hypoxic pulmonary vasoconstriction involves $\mathrm{ET}_{\mathrm{A}}$ receptor-mediated inhibition of $\mathrm{K}_{\mathrm{ATP}}$ channel. Am J Physiol. 2000;278:L434-L442.

95 Nishida M, Eshiro K, Okada Y, Takaoka M, Matsumura Y. Roles of endothelin $\mathrm{ET}_{\mathrm{A}}$ and $\mathrm{ET}_{\mathrm{B}}$ receptors in the pathogenesis of monocrotaline-induced pulmonary hypertension. J Cardiovasc Pharmacol. 2004;44:187-191.

96 Fujita K, Matsumura Y, Kita S, Miyazaki Y, Hisaki K, Takaoka $\mathrm{M}$, et al. Role of endothelin-1 and the $\mathrm{ET}_{\mathrm{A}}$ receptor in the maintenance of deoxycorticosterone acetate-salt-induced hypertension. Br J Pharmacol. 1995;114:925-930.

97 Larivière R, Thibault G, Schiffrin EL. Increased endothelin-1 content in blood vessels of deoxycorticosterone acetate-salt hypertensive but not in spontaneously hypertensive rats. Hypertension. 1993;21:294-300.

98 Larivière R, Day R, Schiffrin EL. Increased expression of endothelin-1 gene in blood vessels of deoxycorticosterone acetatesalt hypertensive rats. Hypertension. 1993;21:916-920.

99 Barton M, d'Uscio LV, Shaw S, Meyer P, Moreau P, Lüscher TF. $\mathrm{ET}_{\mathrm{A}}$ receptor blockade prevents increased tissue endothelin-1, vascular hypertrophy, and endothelial dysfunction in salt-sensitive hypertension. Hypertension. 1998;31(pt2):499-504.

100 Li JS, Larivière R, Schiffrin EL. Effect of a nonselective endothelin antagonist on vascular remodeling in deoxycorticosterone acetate-salt hypertensive rats: evidence for a role of endothelin in vascular hypertrophy. Hypertension. 1994;24:183-188.

101 Fujita K, Matsumura Y, Miyazaki Y, Takaoka M, Morimoto S. Effects of the endothelin $\mathrm{ET}_{\mathrm{A}}$-receptor antagonist FR139317 on development of hypertension and cardiovascular hypertrophy in deoxycorticosterone acetate-salt hypertensive rats. Jpn J Pharmacol. 1996;70:313-319.

102 Matsumura Y, Hashimoto N, Taira S, Kuro T, Kitano R, Ohkita $\mathrm{M}$, et al. Different contribution of endothelin-A and endothelin-B receptors in the pathogenesis of deoxycorticosterone acetatesalt-induced hypertension in rats. Hypertension. 1999;33: 759-765.

103 Pollock DM, Pollock JS. Evidence for endothelin involvement in the response to high salt. Am J Physiol Renal Physiol. 2001; 281:F144-F150.

104 Clozel M, Breu V. The role of $\mathrm{ET}_{\mathrm{B}}$ receptors in normotensive and 
hypertensive rats as revealed by the non-peptide selective $\mathrm{ET}_{\mathrm{B}}$ receptor antagonist Ro 46-8443. FEBS Lett. 1996;383:42-45.

105 Hashimoto N, Kuro T, Fujita K, Azuma S, Matsumura Y. Endothelin $\mathrm{ET}_{\mathrm{B}}$ receptor-mediated action on systemic and renal hemodynamics and urine formation in deoxycorticosterone acetatesalt-induced hypertensive rats. Biol Pharm Bull. 1998;21: 800-804.

106 Bush TL, Barrett-Connor E. Noncontraceptive estrogen use and cardiovascular disease. Epidemiol Rev. 1985;7:89-104.

107 Godsland IF, Wynn V, Crook D, Miller NE. Sex, plasma lipoproteins, and atherosclerosis: prevailing assumptions and outstanding questions. Am Heart J. 1987;114:1467-1503.

108 Stampfer MJ, Colditz GA, Willett WC, Manson JE, Rosner B, Speizer FE, et al. Postmenopausal estrogen therapy and cardiovascular disease. Ten-year follow-up from the nurses' health study. N Engl J Med. 1991;325:756-762.

109 Farhat MY, Lavigne MC, Ramwell PW. The vascular protective effects of estrogen. FASEB J. 1996;10:615-624.

110 Mendelsohn ME, Karas RH. The protective effects of estrogen on the cardiovascular system. N Engl J Med. 1999;340: 1801-1811.

111 Walsh BW, Schiff I, Rosner B, Greenberg L, Ravnikar V, Sacks FM. Effects of postmenopausal estrogen replacement on the concentrations and metabolism of plasma lipoproteins. N Engl J Med. 1991;325:1196-1204.

112 Grady D, Rubin SM, Petitti DB, Fox CS, Black D, Ettinger B, et al. Hormone therapy to prevent disease and prolong life in postmenopausal women. Ann Intern Med. 1992;117:1016-1037.

113 Tolbert T, Oparil S. Cardiovascular effects of estrogen. Am J Hypertens. 2001;14:186S-193S.

114 Miller AP, Chen YF, Xing D, Feng W, Oparil S. Hormone replacement therapy and inflammation interactions in cardiovascular disease. Hypertension. 2003;42:657-663.

115 Florian M, Freiman A, Magder S. Treatment with 17- $\beta$-estradiol reduces superoxide production in aorta of ovariectomized rats. Steroids. 2004;69:779-787.

116 Hulley S, Grady D, Bush T, Furberg C, Herrington D, Riggs B, et al. Randomized trial of estrogen plus progestin for secondary prevention of coronary heart disease in postmenopausal women. JAMA. 1998;280:605-613.

117 Rossouw JE, Anderson GL, Prentice RL, LaCroix AZ, Kooperberg C, Stefanick ML, et al. Risks and benefits of estrogen plus progestin in healthy postmenopausal women: principal results from the women's health initiative randomized controlled trial. JAMA. 1998;288:321-333.

118 Akishita M, Kozaki K, Eto M, Yoshizumi M, Ishikawa M, Toba $\mathrm{K}$, et al. Estrogen attenuates endothelin-1 production by bovine endothelial cells via estrogen receptor. Biochem Biophys Res Commun. 1998;251:17-21.

119 Bilsel AS, Moini H, Tetik E, Aksungar F, Kaynak B, Ozer A. $17 \beta$-Estradiol modulates endothelin-1 expression and release in human endothelial cells. Cardiovasc Res. 2000;46:579-584.
120 Tan Z, Wang TH, Yang D, Fu XD, Pan JY. Mechanisms of $17 \beta$-estradiol on the production of ET-1 in ovariectomized rats. Life Sci. 2003;73:2665-2674.

121 Miyauchi T, Yanagisawa M, Iida K, Ajisaka R, Suzuki N, Fujino $\mathrm{M}$, et al. Age and sex-related variation of plasma endothelin-1 concentration in normal and hypertensive subjects. Am Heart J. 1992;123:1092-1093.

122 Best PJ, Berger PB, Miller VM, Lerman A. The effect of estrogen replacement therapy on plasma nitric oxide and endothelin-1 levels in postmenopausal women. Ann Intern Med. 1998;128: 285-288.

123 Maeda S, Tanabe T, Miyauchi T, Otsuki T, Sugawara J, Iemitsu $\mathrm{M}$, et al. Aerobic exercise training reduces plasma endothelin-1 concentration in older women. J Appl Physiol. 2003;95: 336-341.

124 Polderman KH, Stehouwer CD, van Kamp GJ, Schalkwijk CG, Gooren LJ. Modulation of plasma endothelin levels by the menstrual cycle. Metabolism. 2000;49:648-650.

125 Carbonne B, Mignot TM, Tsatsaris V, Ferré F. Changes in plasma and amniotic fluid endothelin levels during pregnancy: facts or artifacts? Eur J Obstet Gynecol Reprod Biol. 1998;76:15-19.

126 Polderman KH, Stehouwer CD, van Kamp GJ, Dekker GA, Verheugt FW, Gooren LJ. Influence of sex hormones on plasma endothelin levels. Ann Intern Med. 1993;118:429-432.

127 Ergul A, Shoemaker K, Puett D, Tackett RL. Gender differences in the expression of endothelin receptors in human saphenous veins in vitro. J Pharmacol Exp Ther. 1998;285:511-517.

128 Nuedling S, van Eickels M, Alléra A, Doevendans P, Meyer R, Vetter $\mathrm{H}$, et al. $17 \beta$-Estradiol regulates the expression of endothelin receptor type B in the heart. Br J Pharmacol. 2003;140: 195-201.

129 David FL, Carvalho MH, Cobra AL, Nigro D, Fortes ZB, Rebouças NA, et al. Ovarian hormones modulate endothelin-1 vascular reactivity and mRNA expression in DOCA-salt hypertensive rats. Hypertension. 2001;38:692-696.

130 David FL, Montezano AC, Rebouças NA, Nigro D, Fortes ZB, Carvalho $\mathrm{MH}$, et al. Gender differences in vascular expression of endothelin and $\mathrm{ET}_{\mathrm{A}} / \mathrm{ET}_{\mathrm{B}}$ receptors, but not in calcium handling mechanisms, in deoxycorticosterone acetate-salt hypertension. Braz J Med Biol Res. 2002;35:1061-1068.

131 Pedersen SH, Nielsen LB, Pedersen NG, Nilas L, Ottesen B. Hormone therapy modulates ET(A) mRNA expression in the aorta of ovariectomised New Zealand White rabbits. Gynecol Endocrinol. 2009;25:175-182.

132 Pedersen SH, Nielsen LB, Mortensen A, Nilas L, Ottesen B. Progestin oppose the effects of estradiol on the endothelin-1 receptor type B in coronary arteries from ovariectomized hyperlipidemic rabbits. Menopause. 2008;15:503-510.

133 Kitada K, Yui N, Koyama M, Kimura K, Suzuki R, Tanaka R, et al. Endothelin $\mathrm{ET}_{\mathrm{B}}$ receptor is involved in sex differences in the development of balloon injury-induced neointimal formation. J Pharmacol Exp Ther. 2011;336:533-539. 